\title{
PENDUGAAN BIAYA POKOK PRODUKSI DAN PENDAPATAN USAHATANI JAGUNG DI KECAMATAN ADILUWIH KABUPATEN PRINGSEWU
}

\author{
(The Estimation of Standard Cost and Income of Corn Farming in Adiluwih District of Pringsewu \\ Regency)
}

Rizkia Fortuna Utami, Agus Hudoyo, Achdiansyah Soelaiman

Jurusan Agribisnis, Fakultas Pertanian, Universitas Lampung, Jl. Prof. Dr. Soemantri Brodjonegoro No. 1 Bandar Lampung 35145, e-mail: agus.hudoyo@fp.unila.ac.id

\begin{abstract}
The objectives of this study are to analyze the standard cost and the income of corn farming in Adiluwih District, Pringsewu Regency. Respondents are corn farmers chosen by using simple random sampling method. Data were collected by interviewing the respondents on the corn farming in the Rainy Season (RS) 2016/2017 and the Dry Season (DS) 2017. The data were analyzed by using the economic and financial analysis. The average corn productivities were 2.84 ton/ha in RS 2016/2017 and 2.75 ton/ha in DS 2017. The average standard costs for producing corn was IDR2,927/kg and its $95 \%$ confidence interval was IDR2,168/ $\mathrm{kg}$ - IDR3,686/kg. The average net income over its cash costs was IDR5.73 million/ha, the same amount in RS 2016/2017 and in DS 2017. The net income over its total cost was IDR3.57 million/ha in $R S 2016 / 2017$ and also in DS 2017
\end{abstract}

Key words: confidence interval, corn, income, standard cost

\section{PENDAHULUAN}

Jagung adalah komoditas unggulan jagung Indonesia untuk memenuhi kebutuhan pangan dan pakanbagihewan ternak.Jagung merupakan salah satu bahan baku utama dalam industri pakan ternak unggas. Perkembangan industri ternak unggas mendorong peningkatan kebutuhan akan jagung (BPPKP2017).

Data FAO tahun 2017 diperkirakan jumlah jagung untuk pangan sebesar 8,44 juta ton, pakan sebesar 4,31 juta ton, benih sebesar 0,14 juta ton, penggunaan lainnya sebesar 3,03 juta ton dan tercecer sebesar 1,09 juta ton. Total kebutuhan untuk jagung jagung adalah sebesar 17,01 juta ton. Sementara itu, produksi jagung sebesar 15,95juta ton.Hal ini berarti produksi jagung lebih kecil dari kebutuhan jagung dan tercecer, yakni selisihnya sebesar 1,06 juta ton (FAO2019).

Defisit antara produksi dan kebutuhan jagung tersebut menunjukkan bahwa Indonesia belum mampuberswasembada jagung. Agar tercapainya swasembada, jagung perlu dilakukan peningkatan jumlah produksi melalui intensifikasi dan ekstensifikasi, dengan adanya usaha tersebut maka diharapkan dapat meningkatkan pendapatan usahatani jagung petani. Petani sebagai produsen jagung berperan sangat penting dalam peningkatan produktivitas. Bagi petani, peningkatan produktivitas merupakan salah satu usaha untuk meningkatkan pendapatannya.

Selain peningkatan produksi dan produktivitas, pendapatan petani juga dipengaruhi oleh biaya pokok atau biaya per satuan output.Harga jual yang ditetapkan tidak boleh terlalu tinggi dan juga tidak boleh terlalu rendah karena akanmerugikan produsen dan konsumen.Dalam hal ini, pemerintah menetapkan harga acuan untuk melindungi petani dalam berusahatani.Harga acuan diatur dalam Peraturan Menteri Perdagangan Republik Indonesia Nomor 27/M-DAG/PER/5/2017.Harga acuan untuk jagung pipilan yaitu Rp3.150 per kilogram dengan kadar air 15\% (Kementerian Pertanian2017).

Berbagai penelitian mengenai analisis pendapatan usahatani jagung sejauh ini sudah dilakukan oleh peneliti-peneliti terdahulu diantaranya yakni Nedi, Supardi, dan Sutrisno (2013) mengahasilkan pendapatan yang diperoleh petani dalam usahatani jagung menguntungkan dan Sumiati, Antara, dan Muis (2016) menghasilkan bahwa usahatani jagung yang dilakukan menguntungkan dan layak untuk diusahakan. Sementara itu, penelitian 
mengenai analisis harga pokok produksiusahatani jagung sudah dilakukan oleh Solekhah, Zakaria, dan Marlina(2018) menghasilkan harga pokok produksi lebih kecil dari harga jual.

Provinsi Lampung merupakan sentra jagung nasional. Salah satu sentra jagung Provinsi Lampung adalah Kabupaten Pringsewu.Kecamatan Adiluwih menjadi salah satu daerah sentra penghasil jagung di Kabupaten Pringsewu dan sebagai sumber utama pakan ternak. Menurut Dinas Pertanian Kabupaten Pringsewu tahun 2017, produksi jagung di Kecamatan Adiluwih saat ini mengalami pasang surut, yaitu pada tahun 2014 produksi mencapai 17.556 ton, tahun 2015 mencapai 22.750 ton, dan tahun 2016 mencapai 21.700 ton. Tinggi rendah nya produksi yang dihasilkan berpengaruh terhadap pendapatan yang diterima petani.Untuk itu perlu dilakukan penelitian mengenai pendapatan dan biaya pokok produksi jagung.Berdasarkan latar belakang tersebut, penelitian ini bertujuan untuk menganalisis pendapatan dan biaya pokok produksi jagung di Kecamatan Adiluwih Kabupaten Pringsewu.

\section{METODE PENELITIAN}

Penelitian ini dilakukan di Kecamatan Adiluwih Kabupaten Pringsewu tepatnya di Pekon Srikaton, Pekon Waringinsari Timur, dan Pekon Tritunggal Mulya. Pemilihan lokasi dilakukan dengan sengaja (purposive) dengan pertimbangan bahwa Kecamatan Adiluwih merupakan sentra produksi jagung terbesar di Kabupaten Pringsewu.Responden dalam penelitian ini adalah petani jagung dengan jumlah 60 orang, masingmasing pekon berjumlah 20 orang yang dipilih dengan menggunakan metode acak sederhana.

Data yang dikumpulkan dalam penelitian ini yaitu data analisis usahatani jagung, seperti produksi jagung, luas lahan, jumlah pupuk, jumlah pestisida, dan penyusutan alat. Data usahatani diperoleh dengan mewawancarai responden usahatani jagung untuk musim hujan (MH) 2016/2017 dan musim kemarau (MK) 2017. Analisis data yang digunakan adalah:

Pendapatan atas biaya tunai $=$

Penerimaan-biaya tunai

Pendapatan atas biaya total $=$

Penerimaan-biaya total

Keterangan :

Penerimaan $(\mathrm{Rp})=$ Produksi $(\mathrm{kg}) \times$ harga $(\mathrm{Rp} / \mathrm{kg})$
Biaya Tunai (Rp)

= Biaya yang

dikeluarkan

tunai

Biaya Total $(\mathrm{Rp}) \quad=$ Biaya tunai +

Biaya yang

diperhitungkan

Biaya diperhitungkan $(\mathrm{Rp}) \quad$ = Biaya yang

dikeluarkan

tidak tunai

Tujuan kedua dianalisis dengan menggunakan analisis biaya pokok.Secara matematis perhitungan biaya pokok adalah sebagai berikut:

$\mathrm{BP}=\frac{\mathrm{TC}}{\mathrm{Y}}$

Keterangan:

$\mathrm{BP}=$ Biaya pokok $(\mathrm{Rp} / \mathrm{kg})$

$\mathrm{TC}=$ Total $\operatorname{cost}(\mathrm{Rp} / \mathrm{kg})$

$\mathrm{Y}=$ Produksi $(\mathrm{Rp} / \mathrm{kg})$

Setelah diperoleh biaya pokok untuk tiap responden, kemudian dihitung rata-rata biaya pokok dengan rumus sebagai berikut :

$\mathrm{BP}=\frac{\sum_{\mathrm{i}=1}^{\mathrm{n}} \mathrm{BP} \mathrm{i}}{\mathrm{n}}$

Keterangan:

$\mathrm{BP}=$ Rata-rata biaya pokok $(\mathrm{Rp} / \mathrm{kg})$

$\mathrm{BP}_{\mathrm{i}}=$ Biaya pokok untuk responden ke-i $(\mathrm{Rp} / \mathrm{kg})$

$\mathrm{n} \quad=$ Jumlah responden

Rata-rata biaya pokok yang telah didapat kemudian dilakukan perhitungan selang kepercayaan dengan menggunakan tingkat kepercayaan sebesar 95 persen $(\alpha=5 \%)$. Perhitungan selang kepercayaan biaya pokok dapat dilihat sebagai berikut (Walpole1995):

$\mathrm{BP}-t_{\alpha / 2} \frac{s}{\sqrt{n}}<\overline{B P}<\overline{B P}+t_{\alpha / 2} \frac{s}{\sqrt{n}}$

Keterangan :

$\mathrm{BP} \quad=$ Rata-rata biaya pokok $(\mathrm{Rp} / \mathrm{kg})$

$\mathrm{s} \quad=$ Simpangan baku $(\mathrm{Rp} / \mathrm{kg})$

$\alpha \quad=$ Taraf nyata $(5 \%)$

$\mathrm{n} \quad=$ Jumlah responden

\section{HASIL DAN PEMBAHASAN}

Responden pada penelitian ini adalah petani jagung di Kecamatan Adiluwih yang berjumlah 60 orang. Usia petani jagung yaitu berkisar antara 44-56 tahun.Tingkat pendidikan sebagian besar petani 
responden adalah SD, yakni sebanyak 23 orang(38\%).Jumlah tanggungan keluarga petani jagung, yaitu 3-4 orang.Sebagian besar petani responden memiliki pengalaman berusahatani antara 23-33 tahun.

\section{Penggunaan input dan biaya}

Rata-rata petani jagung memiliki luas lahansebesar 0,59 ha dengan status penguasaan lahan adalah milik sendiri. Rata-rata input, output, biaya dan pendapatan usahatani jagung per hektar dapat dilihat pada Tabel 1 untuk Musim Hujan (MH) 2016/2017 dan Tabel 2 untuk Musim Kemarau (MK) 2017.Rata-rata penggunaan benih jagung pada MH 2016/2017 dan MK 2017 adalah sebesar
$17,63 \mathrm{~kg} / \mathrm{ha}$ dan $17,73 \mathrm{~kg} / \mathrm{ha}$. Sementara itu, pada penelitian Sumiati et al (2016) benih yang digunakan adalah sebesar 16,12kg/ha.

Berdasarkan anjuran dari BPTP (2016), penggunaanbenih jagung yaitu $15-30 \mathrm{~kg} / \mathrm{ha}$. Hal tersebut berarti bahwa penggunaan benih jagung yang digunakan oleh petani di daerah penelitian dengan penelitian sebelumnya sudah sesuai dengan anjuran. Petani jagung di Kecamatan Adiluwih mayoritas menggunakan varietas benih jagung hibrida. Merek dagang benih hibrida yang banyak digunakan adalah Pertiwi 27 dan Pioner.

Tabel 1.Rata-rata input dan output usahatani jagung per hektar pada MH 2016/2017

\begin{tabular}{|c|c|c|c|c|c|c|c|c|}
\hline \multirow{2}{*}{ Uraian } & \multirow{2}{*}{ Satuan } & \multicolumn{2}{|c|}{ Fisik } & \multirow{2}{*}{ Jumlah } & \multirow{2}{*}{$\begin{array}{l}\text { Harga } \\
\text { (Rp/sat) }\end{array}$} & \multicolumn{3}{|c|}{ Nilai $(\mathrm{Rp})$} \\
\hline & & DK & LK & & & Diperhitungkan & Tunai & Total \\
\hline \multicolumn{9}{|l|}{ 1. Biaya input } \\
\hline Benih & $\mathrm{Kg}$ & & 17,63 & 17,63 & 75.117 & & 1.324 .557 & 1.324 .557 \\
\hline Pupuk Urea & $\mathrm{Kg}$ & & 361,22 & 361,22 & 2.000 & & 722.444 & 722.444 \\
\hline Pupuk Phonska & $\mathrm{Kg}$ & & 287,83 & 287,83 & 2.585 & & 744.049 & 744.049 \\
\hline Pupuk kandang & $\mathrm{Kg}$ & & $3.051,67$ & $3.051,67$ & 337 & & 1.027 .394 & 1.027 .394 \\
\hline Herbisida & Liter & & 2,00 & 2,00 & 65.000 & & 130.000 & 130.000 \\
\hline Insektisida & Liter & & 0,97 & 0,97 & 350.000 & & 338.333 & 338.333 \\
\hline \multicolumn{9}{|l|}{ 2. Tenaga kerja } \\
\hline \multicolumn{9}{|l|}{ Pengolahan tanah } \\
\hline Mesin & Jam & & 7,63 & 7,63 & * & & 800.000 & 800.000 \\
\hline Orang & HOK & 0,09 & 6,28 & 6,37 & 60.000 & 5.667 & 376.667 & 382.333 \\
\hline Penanaman & HOK & 1,34 & 4,41 & 5,75 & 60.000 & 80.333 & 264.667 & 345.000 \\
\hline Pemupukan 1 & HOK & 1,76 & 2,81 & 4,57 & 60.000 & 105.583 & 168.375 & 273.958 \\
\hline Pemupukan 2 & HOK & 1,45 & 2,65 & 4,10 & 60.000 & 87.292 & 158.750 & 246.042 \\
\hline Penyiangan & HOK & 2,59 & 1,33 & 3,92 & 60.000 & 155.125 & 79.875 & 235.000 \\
\hline \multicolumn{9}{|l|}{ 3. Biaya Lain-lain } \\
\hline Sewa lahan & $\mathrm{Rp}$ & & & & & 1.179 .792 & & 1.179 .792 \\
\hline Pajak & $\mathrm{Rp}$ & & & & & & 20.188 & 20.188 \\
\hline Penyusutan alat & $\mathrm{Rp}$ & & & & & 193.107 & & 193.107 \\
\hline Bunga Modal & $\mathrm{Rp}$ & & & & & 348.494 & & 348.494 \\
\hline $\begin{array}{l}\text { Biaya } \\
\text { Produksi }\end{array}$ & & & & & & 2.155 .393 & 6.155 .299 & 8.310 .692 \\
\hline Tongkol & $\mathrm{Kg}$ & & & 5.168 & 2.300 & & & 11.887 .167 \\
\hline $\begin{array}{l}\text { Pipilan } \\
\text { Pendapatan atas biava }\end{array}$ & $\mathrm{Kg}$ & & & 2.843 & & & & \\
\hline $\begin{array}{l}\text { tunai } \\
\text { Pendapatan atas biaya }\end{array}$ & $\mathrm{Rp}$ & & & & & & & 5.731 .867 \\
\hline total & $\mathrm{Rp}$ & & & & & & & 3.576 .474 \\
\hline
\end{tabular}


Pemupukan dilakukan untuk meningkatkan kesuburan tanah dan menyediakan hara bagi tanaman.Pupuk yang digunakan oleh petani jagung berupa pupuk organik (kandang) dan pupuk anorganik yang terdiri dari pupuk urea dengan bahan aktif nitrogen (N) dan pupuk majemuk $(\mathrm{N}, \mathrm{P}, \mathrm{K})$, yaitu phonska. Pupuk unsur $\mathrm{N}$ diberikan pada saat fase vegetatif untuk mempercepat pertumbuhan tunas dan batang. Pada saat fase generatif pupuk yang diberikan adalah pupuk yang mengandung unsur fosfor (P2O) untuk merangsang pertumbuhan bunga, benih dantanaman muda, dan pupuk yang mengandung unsur Kalium (K) untuk membantu pembentukan protein dan karbohidrat pada perkembangan buah.Kalium pun berperan dalam memperkuat tanamandalam menghadapi kekeringan dan penyakit (BPTP Sulawesi Utara 2015). Penggunaan pupuk yang dilakukan oleh petani jagung di Kecamatan Adiluwih sudah sesuai dengan anjuran yang diberikan.

Penggunaan pestisida oleh petani bertujuan untuk mengendalikan hama dan penyakit pada tanaman. Herbisida jenis paratov digunakan untuk mengendalikan hama rumput dan insektisida jenis Regent digunakan untuk hama ulat, semut, dan belalang. Pestisida yang digunakan pada $\mathrm{MH}$ 2016/2017 dan MK 2017 hampir sama, yakni herbisida sebanyak 1,00 liter/ha, dan insektisida 0,50 liter/ha.

Tabel 2.Rata-rata input dan output usahatani jagung per hektar pada MK 2017

\begin{tabular}{|c|c|c|c|c|c|c|c|c|}
\hline \multirow{2}{*}{ Uraian } & \multirow{2}{*}{ Satuan } & \multicolumn{2}{|c|}{ Fisik } & \multirow{2}{*}{ Jumlah } & \multirow{2}{*}{$\begin{array}{l}\text { Harga } \\
\text { (Rp/sat) }\end{array}$} & \multicolumn{3}{|c|}{ Nilai (Rp) } \\
\hline & & DK & LK & & & Diperhitungkan & Tunai & Total \\
\hline \multicolumn{9}{|l|}{ 1. Biaya input } \\
\hline Benih & $\mathrm{Kg}$ & & 17,73 & 17,73 & 72.217 & & 1.280 .642 & 1.280 .642 \\
\hline Pupuk Urea & $\mathrm{Kg}$ & & 361,22 & 361,22 & 2.000 & & 722.444 & 722.444 \\
\hline Pupuk Phonska & $\mathrm{Kg}$ & & 258,94 & 258,94 & 2.585 & & 669.371 & 669.371 \\
\hline Pupuk kandang & $\mathrm{Kg}$ & & $3.051,67$ & $3.051,67$ & 335 & & 1.022 .308 & 1.022 .308 \\
\hline Herbisida & Liter & & 1,60 & 1,60 & 65.000 & & 104.000 & 104.000 \\
\hline Insektisida & Liter & & 0,63 & 0,63 & 350.000 & & 221.667 & 221.667 \\
\hline \multicolumn{9}{|l|}{ 2. Tenaga kerja } \\
\hline \multicolumn{9}{|l|}{ Pengolahan tanah } \\
\hline Mesin & Jam & & 6,98 & 6,98 & $*$ & & 800.000 & 800.000 \\
\hline Orang & HOK & 0,08 & 6,18 & 6,26 & 60.000 & 5.000 & 370.667 & 375.667 \\
\hline Penanaman & HOK & 1,90 & 3,62 & 5,52 & 60.000 & 114.000 & 217.000 & 331.000 \\
\hline Pemupukan 1 & HOK & 1,79 & 2,69 & 4,48 & 60.000 & 107.375 & 161.250 & 268.625 \\
\hline Pemupukan 2 & HOK & 2,44 & 1,15 & 3,59 & 60.000 & 146.375 & 69.000 & 215.375 \\
\hline Penyiangan & $\mathrm{HOK}$ & 1,49 & 1,95 & 3,44 & 60.000 & 89.500 & 117.125 & 206.625 \\
\hline \multicolumn{9}{|l|}{ 3. Biaya lain-lain } \\
\hline Sewa lahan & $\mathrm{Rp}$ & & & & & 1.179 .792 & & 1.179 .792 \\
\hline Pajak & $\mathrm{Rp}$ & & & & & & 20.188 & 20.188 \\
\hline Penyusutan alat & $\mathrm{Rp}$ & & & & & 193.107 & & 193.107 \\
\hline Bunga modal & $\mathrm{Rp}$ & & & & & 323.343 & & 323.343 \\
\hline $\begin{array}{l}\text { Biaya } \\
\text { Produksi }\end{array}$ & $\mathrm{Rp}$ & & & & & 2.158 .492 & 5.775 .662 & 7.934 .154 \\
\hline Tongkol & $\mathrm{Kg}$ & & & 5.003 & 2.300 & & & 11.505 .750 \\
\hline $\begin{array}{l}\text { Pipilan } \\
\text { Pendapatan atas }\end{array}$ & $\mathrm{Kg}$ & & & 2.751 & & & & \\
\hline $\begin{array}{l}\text { biaya tunai } \\
\text { Pendapatan atas }\end{array}$ & & & & & & & & 5.730 .088 \\
\hline biaya total & & & & & & & & 3.571 .596 \\
\hline
\end{tabular}


Tabel 3. Rata-rata biaya pokok produksi jagung

\begin{tabular}{lrr}
\hline Uraian & $\begin{array}{c}\text { Nilai } \\
(\mathrm{Rp} / \mathrm{kg})\end{array}$ & $\begin{array}{c}\text { Persentase } \\
(\%)\end{array}$ \\
\hline Biaya & & \\
Benih & 469,00 & 16,00 \\
Pupuk & 884,00 & 30,00 \\
Pestisida & 143,00 & 5,00 \\
Penyusutan & 70,00 & 2,00 \\
Pajak & 7,00 & 0,00 \\
Sewa lahan & 425,00 & 15,00 \\
Tenaga Kerja & 807,00 & 28,00 \\
Bunga Modal & 121,00 & 4,00 \\
Total (Biaya Pokok) & $2.927,00$ & 100,00 \\
Selang kepercayaan 95\% & & \\
Batas Bawah & $2.168,00$ & \\
Batas Atas & $3.686,00$ & \\
\hline
\end{tabular}

Usahatani jagung terdiri dari berbagai kegiatan yang menggunakan tenaga kerja luar keluarga dan dalam keluarga, diantaranya pengolahan tanah, penanaman, pemupukan 1 dan pemupukan 2, serta penyiangan. Penggunaan tenaga kerjabanyak digunakan oleh petani yaitu pada kegiatan pengolahan tanah.Pengolahan tanah menggunakan traktor dengan sistemborongan.Rata-rata borongannya adalah sebesar Rp800.000,00/ha.Petani di Kecamatan Adiluwih tidak menggunakan tenaga kerja untuk panen, karena kegiatan panen menggunakan sistem borongan dan biaya ditanggung oleh tengkulak.

Rata-rata biaya tunai usahatani jagung pada $\mathrm{MH}$ 2016/2017 dan MK 2017 adalah sebesar Rp6,15 juta/ha dan Rp5,77 juta/ha. Rata-rata biaya diperhitungkan pada MH 2016/2017 dan MK 2017 adalah sebesar Rp2,15 juta/ha. Rata-rata biaya total pada MH 2016/2017 dan MK 2017 adalah sebesar Rp8,31 juta/ha dan Rp7,93 juta/ha.

\section{Produksi, penerimaan dan pendapatan}

Rata-rata produksi jagung pada MH 2016/2017 dan MK 2017adalah sebesar 2,84 ton/ha dan 2,75 ton/ha dalam bentuk jagung pipilan.Harga jual jagung pipilan ditingkat petani yaitu sebesar Rp5.000,00/kg.Oleh sebab itu, penerimaan usahatani jagung pada MH 2016/2017 dan MK 2017 adalah sebesar Rp11,88 juta/ha dan Rp11,50 juta/ha. Pendapatan atas biaya tunai pada $\mathrm{MH}$ 2016/207 dan MK 2017 sama, adalah sebesar Rp5,73 juta/ha dan pendapatan atas biaya total pada MH 2016/2017 dan MK 2017 sama, adalah sebesar Rp3,57 juta/ha.

\section{Biaya pokok produksi jagung}

Biaya pokok diperoleh dari semua biaya yang dikeluarkan petani yang terdiri dari biaya benih, pupuk, pestisida, penyusutan alat, pajak, sewa lahan, tenaga kerja, dan bunga modal.Biaya pokok dirata-ratakan untuk dua musim tanam, yakni $\mathrm{MH}$ 2016/2017 dan MK 2017.Rata-rata biaya pokok produksi jagung dijelaskan pada Tabel 3 .

Tabel 3 menunjukkan bahwa rata-rata biaya pokok adalah sebesar Rp2.927,00/kg.Biaya tertinggi adalah biaya pupuk yaitu sebesar $\mathrm{Rp} 884,00 / \mathrm{kg}$ (30\%). Biaya tertinggi setelah pupuk adalah biaya tenaga kerja sebesar Rp807,00/kg (28\%).Selang kepercayaan 95 persen biaya pokok produksi jagung yaitu antara Rp2.168,00/kg dan Rp3.686,00/kg pipilan.Sementara itu, harga acuan untuk jagung yang telah ditetapkan pemerintah yaitu Rp3.150,00/kg pipilan (Peraturan Menteri Perdagangan Republik Indonesia Nomor 27/MDAG/PER/5/2017).Harga acuan ini masih jauh di bawah batas tertinggi rata-rata biaya pokok.Berdasarkan hal tersebut, perlunya harga output jagung di batas tertinggi selang kepercayaan. Oleh karena itu, harga acuan disarankan dari Rp3.150,00/kg menjadi sebesar $\mathrm{Rp3} .686,00 / \mathrm{kg}$ pipilan.

\section{KESIMPULAN}

Rata-rata produktivitas jagung pada $\mathrm{MH}$ 2016/2017 dan MK 2017adalah sebesar 2,84 ton/ha dan 2,75 ton/ha jagung pipilan.Rata-rata pendapatan atas biaya tunai pada MH 2016/2017 dan MK 2017 sama, adalah sebesar Rp5,73 juta/ha. Rata-rata pendapatan atas biaya totalsama, adalah sebesar Rp3,57 juta/ha.Rata-rata biaya pokok usahatani jagung adalah sebesar Rp2.927,00/kg dengan selang kepercayaan 95 persen antara Rp2.168,00/kg dan Rp3.686,00/kg jagung.

\section{DAFTAR PUSTAKA}

BPPKP [Badan Pengkajian dan Pengembangan Kebijakan Perdagangan]. 2017. Potret Jagung Indonesia : Menuju Swasembada Tahun 2017. http://bppp.kemendag.go.id/media_content/201 7/08/Potret_Jagung_Indonesia_Menuju_Swase mbada_Tahun 2017.pdf [29 Januari 2019].

BPTP [Balai Pengkajian Teknologi Pertanian]. 2016.Anjuran penggunaan pupuk pada tanaman jagung.www.lampung.litbang.pertanian.go.id [29 Januari 2019]. 
BPTP[Balai Pengkajian Teknologi Pertanian] Sulawesi Utara. 2015. Anjuran penggunaan pupuk pada tanaman jagung.http://sulut.litbang.petanian.go.id/ind/in dex.php?option $=$ com_content $\&$ view $=$ article $\&$ id $=582 \&$ Itemid $=65[27$ Agustus 2019] .

Dinas Pertanian Kabupaten Pringsewu. 2017. Produksi dan Luas Panen Jagung di Kabupaten Pringsewu. Pringsewu.

FAO [Food and Agriculture Organization]. 2019.www.fao.org/faostat/en/\#data/fbs.[24 September 2019].

Kementerian Pertanian. 2017. Outlook Tanaman Pangan dan Hortikultura 2017. Pusat Data dan Sistem Informasi Pertanian, Sekretariat Jendral, Jakarta.

NediB, Supardi S dan Sutrisno J. 2013. Analisis Usahatani jagung di Kabupaten Grobogan Provinsi Jawa Tengah.Jurnal Agro Ekonomi, 22(2):146- 199.http://media.neliti.com/media/publicationsanalisis-usahatani-jagung. [29 Januari 2019]

Sumiati AL, Antara M, dan Muis A. 2016. Analisis pendapatan usahatani jagung Di Desa Labuan Toposo Kecamatan Labuan Kabupaten Donggala.Jurnal e-J. Agrotekbis, 4 (4) : 456460.https://media.neliti.com/media/publications /242845-analisis-pendapatan-usahatani-jagungdi-161dd1c5. [29Januari 2019].

Solekhah F, Zakaria WA dan Marlina L. 2018. Analisis harga pokok produksi dan harga pokok penjualan jagung di Kecamatan SekampungUdik Kabupaten Lampung Timur.JIIA, 6(4):422429.http://jurnal.fp.unila.ac.id/index.php/JIIA/ar ticle/view/3111/2478[24 September 2019].

Walpole RE. 1995. Pengantar Statistika, edisi ketiga. Penerbit PT. Gramedia Pustaka Utama.Jakarta. 